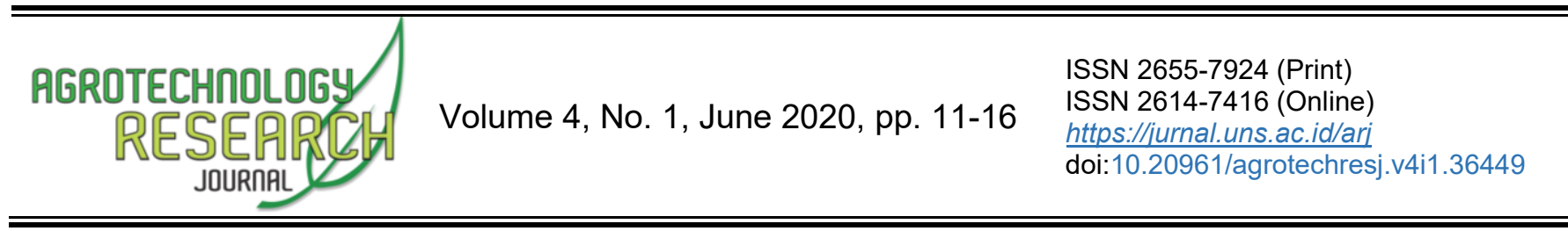

\title{
Identifikasi Keragaman dan Dominansi Gulma pada Lahan Pertanaman Kedelai
}

\author{
Vidya Imaniasita $^{1^{*}}$, Twenty Liana ${ }^{2 *}$, Krisyetno ${ }^{3}$, Dayu Satriyo Pamungkas ${ }^{4}$ \\ ${ }^{1-4}$ Central Kalimantan Assessment Center of Agricultural Technology, Palangka Raya, Indonesia
}

Received 3 December 2019; Accepted 22 February 2020; Published 25 June 2020

\begin{abstract}
The diversity and dominance of weeds is the first step in determining the success of weed control. This study aimed to identify the diversity and dominance of weeds in the cultivation of soybean under the shade of oil palm that have not produced (1 year). This research was conducted in October 2018 to January 2019. Sampling used a phrase with a frame size of $1 \times 1 \mathrm{~m}$. Weed samples were collected and identified per species according to weed groups, then counted with Summed Dominance Ratio to get weed dominance at each location. There were 10 weed families in soybean cultivation consisting of two types of weed grass, seven types of broadleaf weeds, and two types of weed puzzles. The dominant weed family in soybean cultivation was found in the Poaceae family, with Imperata cylindrica species.
\end{abstract}

Keywords: Poaceae; Imperata cylindrica; Summed Dominance Ratio; Glycine max

Cite This As (CSE Style): Imaniasita V, Liana T, Krisyetno, Pamungkas DS. 2020. Identifikasi Keragaman dan Dominansi Gulma pada Lahan Pertanaman Kedelai. Agrotech Res J 4(1): 11-16. https://doi.org/10.20961/agrotechresj.v4i1.36449

\section{PENDAHULUAN}

Gulma merupakan tumbuhan yang mengganggu pertumbuhan tanaman budidaya atau merugikan kepentingan manusia sehingga manusia berusaha untuk mengendalikannya (Sembodo 2010; Kilkoda, et al. 2015). Keberadaan gulma pada tanaman budidaya mengakibatkan adanya kompetisi dalam hal pengambilan air, unsur hara, ruang tumbuh serta cahaya matahari yang dapat merugikan tanaman budidaya. $\mathrm{Di}$ samping itu gulma dapat mengeluarkan senyawa allelopathy serta dapat menjadi inang bagi hama dan patogen tanaman budidaya. Kerugian yang diakibatkan oleh gulma ini akan menurunkan hasil panen pada tanaman budidaya (Aldrich, RJ 1984; Aldrich, R.J. 1997; Kastanja 2015; Kilkoda et al. 2015; Hidayat dan Rachmadiyanto 2017).

Jenis gulma meliputi gulma rumput (grasses), gulma golongan tekian (sedges) dan gulma golongan berdaun lebar (broad leaves) (Caton et al. 2011). Gulma pada tanaman kedelai (Glycine max (L.) Merill) menyebabkan terjadinya persaingan dalam pengambilan unsur hara, air, cahaya dan ruang tumbuh (Umiyati, $U$ dan Kurniadie 2016; Gultom et al. 2017). Semakin lama gulma berada pada areal pertanaman akan mengakibatkan jumlah daun semakin berkurang. Persaingan antara gulma dan tanaman kedelai semakin meningkat dalam

\footnotetext{
${ }^{*}$ Corresponding Authors:

${ }^{1} E$-Mail: vidyama21@gmail.com

${ }^{2}$ E-Mail: twentylianabptp.kalteng09@gmail.com
}

mendapatkan faktor tumbuh yang dibutuhkan untuk pertumbuhan daun tersebut (Hendrival et al. 2014). Kompetisi tanaman kedelai dengan gulma menyebabkan kekurangan hasil sampai $80 \%$ (Silva et al. 2015), tanaman kerdil, daun menguning dan produksi rendah (Najiyati dan Danarti 2003; Solahudin et al. 2010; Palijama 2012; Sari dan Rahayu 2013; Purnamasari et al. 2017; Tampubolon et al. 2018). Apabila gulma dibiarkan pada areal pertanaman kedelai dari awal tanam hingga panen akan menyebabkan penurunan berat bobot biji kering sehingga hasil kedelai berkurang (Hendrival et al. 2014), dan dapat menimbulkan keracunan bagi tanaman pokok yang dikenal sebagai alelopati dan mempersulit pekerjaan di lapangan (Umiyati dan Kurniadie 2016).

Keragaman gulma dipengaruhi oleh kondisi lingkungan (Perdana et al. 2013). Banyak faktor yang mempengaruhi keragaman gulma pada tiap lokasi pengamatan, seperti cahaya, unsur hara, pengolahan tanah, cara budidaya tanaman, serta jarak tanam atau kerapatan tanaman yang digunakan berbeda serta umur tanaman jeruk tersebut. Spesies gulma juga dipengaruhi oleh kerapatan tanaman, kesuburan tanah, pola budidaya dan pengolahan tanah (Aldrich, 1997). Sebaran gulma antara satu daerah dengan daerah lainnya berbeda sesuai dengan faktor yang mempengaruhinya. Identifikasi gulma serta pengenalan jenis-jenis gulma dominan merupakan langkah awal dalam menentukan keberhasilan pengendalian gulma. Penelitian ini bertujuan untuk mengetahui keragaman dan dominansi gulma di lahan pertanaman kedelai. 


\section{BAHAN DAN METODE}

\section{Area penelitian}

Penelitian ini dilaksanakan pada lahan pertanaman kedelai di Desa Santilik Kecamatan Mentaya Hulu, Kabupaten Kotawaringin Timur (studi kasus Tahun 2018). Lokasi penelitian merupakan lahan kering yang berada pada ketinggian \pm 68 meter di atas permukaan laut (mdpl), koordinat lokasi -1 ${ }^{\circ} 57^{\prime 2} 29^{\prime \prime}$ LS dan 112 $37^{\prime} 31^{\prime \prime}$ BT dan tipe iklim dengan klasifikasi tipe B yakni tergolong dalam kondisi iklim basah, dengan luas lahan sebanyak 4 lahan. Penelitian ini dilaksanakan pada bulan Oktober 2018 sampai Januari 2019.

\section{Penanaman tanaman kedelai}

Lahan tanaman sawit merupakan lahan kering sehingga perlu pengolahan tanah yang intensif, yaitu tanah dibajak 2 kali sedalam $30 \mathrm{~cm}$, dibersihkan dari gulma, kemudian tanah diolah dengan hand tractor rotary. Kemudian dibuat saluran drainase setiap 2 gang tanaman kelapa sawit, sedalam $20-25 \mathrm{~cm}$, lebar $20 \mathrm{~cm}$.

Penanaman kedelai dilakukan dengan cara tugal, dengan jarak tanam $40 \mathrm{~cm} \times 20 \mathrm{~cm}$ atau $40 \mathrm{~cm} \times 15 \mathrm{~cm}$, dua biji per lubang. Jarak dari tanam kedelai dengan pohon kelapa sawit) 0,5 sampai $1 \mathrm{~m}$. Populasi tanaman kedelai pada sela tanaman kelapa sawit antara 280.000 - 400.000/ha. Penanaman di lahan kering masam di sela-sela tanaman kelapa sawit, dosis pupuk yang diberikan $50 \mathrm{~kg}$ Urea $+100 \mathrm{~kg} \mathrm{SP}-36+100 \mathrm{KCl}+100 \mathrm{~kg}$ $\mathrm{NPK}+1.500 \mathrm{~kg}$ Dolomit/ha. Dolomit diberikan bersamaan pengolahan tanah yang kedua, ditabur secara merata kemudian di traktor atau di cangkul. Pupuk Urea, SP-36, dan $\mathrm{KCl}$ di berikan pada tanaman berumur 10 hari setelah tanam, paling lambat 14 hari setelah tanam. Pupuk diberikan dengan cara di tugal atau tabur pada larikan 5-7 $\mathrm{cm}$ dari tanaman. Dosis pupuk Urea diberikan dalam jumlah yang rendah di karena tanaman kacang kedelai dapat menangkap unsur $\mathrm{N}$ dari udara. Di samping itu tanaman kedelai mempunyai bintil akar yang dapat membantu kesuburan tanah.

Komponen teknologi yang akan diterapkan di masing-masing pertanaman kedelai adalah pemberian pupuk dasar yaitu: (1) pupuk hayati (biofertilizer) berbahan aktif mikroba penambat nitrogen bebas, penghasil zat pengatur tumbuh (ZPT), pelarut fosfat dan perombak bahan organik (450 kg /ha), (2) Pupuk Kandang (750 kg/ha), dan (2) Campuran pupuk hayati (biofertilizer) berbahan aktif mikroba penambat nitrogen bebas, penghasil zat pengatur tumbuh (ZPT), pelarut fosfat dan perombak bahan organik + pupuk kandang $(210 \mathrm{~kg} / \mathrm{ha}+375 \mathrm{~kg} / \mathrm{ha})$

\section{Pembuatan petak dan pengambilan sampel}

Pengumpulan sampel gulma dilakukan dengan mengambil gulma secara langsung dengan metode kuadrat yang berukuran $1 \times 1 \mathrm{~m}$ pada petak-petak contoh. Titik pengambilan sampel gulma dipilih secara acak dan dilakukan sebanyak sepuluh kali. Data yang dikumpulkan meliputi jumlah individu, nama jenis dan kelindungan masing-masing jenis. Pengambilan dilakukan secara manual dengan menggunakan tangan seperti proses penyiangan pada umumnya. Pengambilan sampel gulma pada setiap titik menggunakan bingkai atau frame, kemudian gulma dibersihkan dari lumpur atau kotoran yang menempel di sekitar perakaran dan selanjutnya dilakukan identifikasi. Identifikasi gulma yang ditemukan dari masing-masing titik pengamatan dilakukan dengan cara melihat secara visual bentuk morfologi gulma tersebut, kemudian dicocokkan dengan pustaka (Caton et al. 2011).

\section{Analisis data}

Proses analisis data dilakukan untuk mengetahui jenis dan dominansi gulma pada areal tersebut. Untuk mengetahui jenis gulma dilakukan dengan cara desk study berdasarkan buku identifikasi Barnes dan Chandapillai (1972) serta Moody et al. (1984). Sementara untuk mengetahui jenis gulma dominan dilakukan dengan cara mencari nilai Summed Dominance Ratio (SDR). Dimana nilai SDR tersebut diperoleh dari perhitungan nilai Kerapatan Nisbi Suatu Spesies (KNSS), Dominansi Nisbi Suatu Spesies (DNSS), Frekuensi Nisbi Suatu Spesies (FNSS) serta Nilai Penting (NP). Perhitungan nilai-nilai tersebut menggunakan persamaan menurut (Tjitrosoedirdjo et al. 1984) sebagai berikut:

\section{Kerapatan nisbi suatu spesies}

$$
\text { KNSS }(\%)=\frac{\text { Kerapatan mutlak jenis itu }}{\text { Jumlah kerapatan mutlak semua jenis }} \times 100 \%
$$

dengan kerapatan mutlak suatu jenis sama dengan jumlah individu jenis itu dalam petak contoh.

\section{Dominansi nisbi suatu spesies}

$$
\text { DNSS }(\%)=\frac{\text { Nilai dominansi mutlak suatu jenis }}{\text { Jumlah suatupetak contoh yang diambil }} \times 100 \%
$$

Dominansi mutlak suatu jenis adalah jumlah dari nilai kelindungan atau nilai luas basal atau nilai biomassa atau volume dari jenis itu. Kelindungan dihitung dengan rumus:

$$
\text { Kelindungan }=\frac{\mathrm{d} 1 \times \mathrm{d} 2}{4} \times 2 / n
$$

Dengan $\mathrm{d} 1 \mathrm{dan} \mathrm{d} 2$ adalah diameter proyeksi tajuk suatu jenis

3. Frekuensi nisbi suatu spesies

$$
\text { FNSS }(\%)=\frac{\text { Nilai frekuensi mutlak suatu jenis }}{\text { Jumlah nilai frekuensi mutlak semua jenis }} \times 100 \%
$$

Dengan frekuensi mutlak (FM) suatu jenis diperoleh dari persamaan sebagai berikut :

$$
\mathrm{FM}=\frac{\text { Jumlah petak contoh yang berisi jenis itu }}{\text { Jumlah semua petak contoh yang diambil }}
$$

\section{Nilai Penting (NP)}

$\mathrm{NP}=$ Kerapatan nisbi + Dominansi nisbi + Frekuensi nisbi

5. $\mathrm{SDR}=\mathrm{NP} / 3$

6. Nilai Indeks Shannon - Wiener $\left(\mathrm{H}^{\prime}\right)$

$$
\mathrm{H}^{\prime}=-\sum_{n=1}^{n}\left(\frac{n i}{N}\right)\left(\ln \frac{n i}{N}\right)
$$

\section{Keterangan:}

$\mathrm{H}^{\prime} \quad$ = Indeks keragaman Shannon - Wiener

ni = Jumlah nilai penting dari masing-masing spesies

$\mathrm{N}=$ Jumlah nilai penting dari suatu spesies

$\ln =$ Logaritma Natural

Kriteria nilai indeks keragaman Shannon - Wiener $\left(\mathrm{H}^{\prime}\right)$ :

$$
\begin{array}{ll}
\mathrm{H}^{\prime}<1 & : \text { menunjukkan keragaman rendah } \\
1<\mathrm{H}^{\prime} \leq 3 & : \text { menunjukkan keragaman sedang } \\
\mathrm{H}^{\prime}>3 & : \text { menunjukkan keragaman tinggi }
\end{array}
$$




\section{HASIL DAN PEMBAHASAN}

\section{Identifikasi tumbuhan pada lahan sebelumnya}

Aplikasi pupuk organik pada lahan penanaman $X$ dilakukan sebelum pengolahan tanah. Lahan pertanaman kedelai merupakan lahan pertanaman kelapa sawit yang belum menghasilkan (umur 1 tahun), tidak terawat dan ditumbuhi semak belukar. Tumbuhan dominan pada lahan untuk pertanaman kedelai adalah akasia, semak berdaun kecil dan jenis gulma rerumputan atau Alang-alang (Imperata cylindrica) dapat dilihat pada Gambar 1.
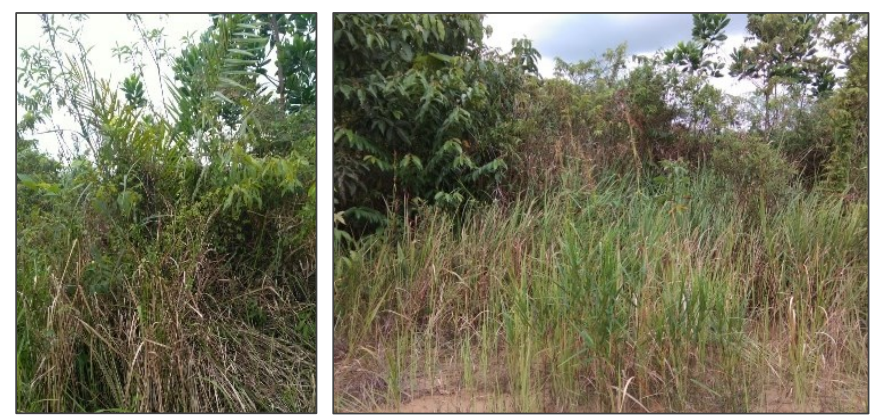

Gambar 1. Kondisi tumbuhan awal pada lahan pertanaman kedelai

\section{Identifikasi gulma}

Hasil pengamatan gulma pada lahan pertanaman kedelai Agromulyo di bawah naungan kelapa sawit di Desa Santilik, Kecamatan Mentaya Hulu, Kabupaten Kotawaringin Timur menunjukkan bahwa jenis gulma yang teridentifikasi secara umum tercatat 13 jenis gulma yang berasal dari 10 famili (Tabel 1) dan beberapa gulma yang teridentifikasi (Gambar 1). Jenis dengan jumlah individu tertinggi berasal dari keluarga Poaceae (rumputrumputan) yaitu Imperata cylindrica sebanyak 433 individu dan Eleusine indica (L.) Gaertn sebanyak 15 individu, dilanjutkan dari famili Cyperaceae sebanyak 104 yaitu Cyperus iria dan Cyperus rotundus. Keberadaan Imperata cylindrica, Eleusine indica (L.) Gaertn, Cyperus iria dan Cyperus rotundus di perkebunan kelapa sawit dapat dilihat pada Mohamad et al. (2010); Saragih et al. (2010) dan Tampubolon et al. (2019).

Pertanaman kedelai dengan pemberian pupuk dasar pupuk kandang kotoran ayam ditemukan lebih banyak gulma dibandingkan pada lahan dengan pemberian pupuk hayati, dan campuran pupuk hayati + pupuk kandang kotoran ayam. Sebanyak 10 famili gulma dijumpai pada pertanaman kedelai dengan pemberian pupuk dasar pupuk kandang kotoran ayam.

Banyaknya jenis gulma yang tumbuh di pertanaman tersebut dapat disebabkan karena adanya tindakan pengolahan tanah dan input pupuk kandang. Syawal, (2009); Tantra dan Santosa (2016); Purnamasari, et al. (2016) menjelaskan bahwa proses pencangkulan pada saat pengolahan tanah dapat menyebabkan terangkatnya biji gulma ke permukaan tanah. Simpanan biji gulma dalam tanah (seedbank) tersebut sewaktu-waktu dapat berkecambah menjadi individu gulma apabila didukung faktor lingkungan.

Jumlah jenis gulma terbanyak dari hasil identifikasi adalah jenis gulma berdaun lebar, yaitu sebanyak 7 jenis, dimungkinkan karena lahan yang cocok untuk pertumbuhan gulma jenis ini. Menurut Tjitrosoepomo et al. (1987), golongan gulma berdaun lebar menyukai tanah sedikit lembap, sedangkan gulma jenis teki dan rumput lebih menyukai lahan terbuka. Di sekitar pertanaman kelapa sawit merupakan lahan yang lembap karena ternaungi oleh tanaman kelapa sawit berumur 1-3 tahun dan pertanaman kedelai.

\section{Analisis vegetasi gulma}

Dominansi merupakan kemampuan suatu gulma untuk dapat bertahan hidup dalam suatu agroekosistem tertentu dengan cara menyaingi gulma lainya. Dominansi dinyatakan dengan istilah biomassa atau kelindungan (coverage) atau volume atau luas basal. Dominansi dinyatakan dengan istilah kelindungan (coverage) atau luas basal atau biomassa atau volume. Dominansi dilihat berdasarkan besarnya nilai SDR suatu gulma, dimana nilai SDR tersebut diperoleh dari nilai kerapatan nisbi, dominansi nisbi, frekuensi nisbi dan nilai penting (Tjitrosoedirdjo et al. 1984).
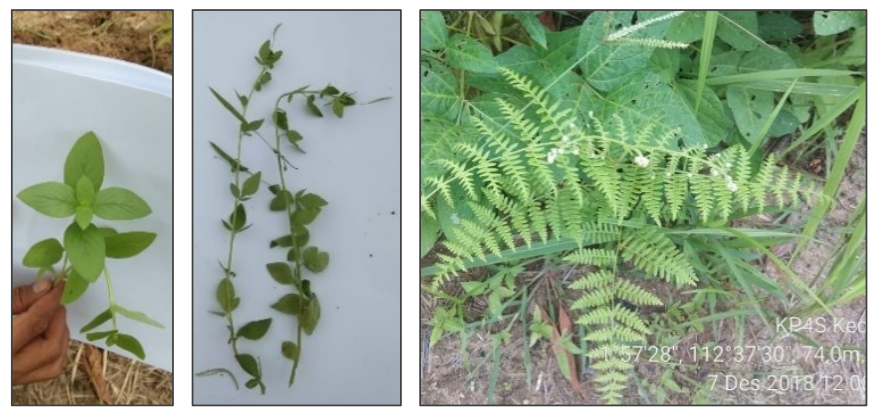

Gambar 2. Beberapa gulma di lahan pertanaman kedelai (Spermacoce alata, Cleome gynandra dan Dicranopteris linearis)

Hasil data analisis SDR gulma pada lahan pertanaman kedelai di bawah naungan kelapa sawit (Tabel 2) menunjukkan gulma yang memiliki nilai SDR tertinggi pada semua perlakuan pemberian pupuk dasar terdapat pada golongan rerumputan, yaitu I. cylindrica sebesar $85,23 \%$. I. cylindrica merupakan tumbuhan rumput menahun yang tersebar hampir di seluruh belahan bumi dan dianggap sebagai gulma pada lahan pertanian (Kartikasari et al. 2013). Garrity et al. (1996) menyatakan bahwa di wilayah Asia Tenggara dapat dijumpai I. cylindrica pada 35 juta ha, dan sekitar 8,5 juta ha tersebar di Indonesia. Rumput ini tumbuh dengan rimpang yang sangat berkembang dan bercabang, dengan sistem rhizomatosa-nya dapat mencapai kedalaman lebih dari $50 \mathrm{~cm}$ (Macdonald et al. 2006; Hidayat dan Rachmadiyanto 2017) yang merupakan $60 \%$ dari biomassa tanaman (Sellers et al. 2012), daunnya panjang 40-90 $\mathrm{cm}$ dan lebar $2 \mathrm{~cm}$, tumbuhnya dikelompokkan di simpul rimpang (Franco et al. 2015). Perbedaan jenis gulma disebabkan oleh terjadinya perbedaan pengelolaan tanaman, antara lain pengaturan air dan pemupukan serta adanya perbedaan morfologi dan karakter tanaman penyusun yang dapat mengubah mikroklimat sehingga menimbulkan respons yang berbeda pada jenis gulma (Mercado 1979). 
Tabel 1. Identifikasi gulma pada lahan pertanaman kedelai di bawah naungan kelapa sawit

\begin{tabular}{llllcccl}
\hline \multirow{2}{*}{ No } & \multirow{2}{*}{ Famili } & \multirow{2}{*}{ Jenis } & \multirow{2}{*}{ Nama Lokal } & \multicolumn{3}{c}{ Jumlah } & \multirow{2}{*}{ Keterangan } \\
\cline { 5 - 6 } & & & L1 & L2 & L3 & \\
\hline 1 & Poaceae & Imperata cylindrica & Alang-alang/tingen & 202 & 92 & 139 & Rerumputan \\
2 & Gleicheniaceae & Dicranopteris linearis & Paku resam & 23 & 8 & 12 & Berdaun lebar \\
3 & Asteraceae & Ageratum houstonianum & Babadotan & 0 & 13 & 2 & Berdaun lebar \\
4 & Solanaseae & Physalis minima $L$. & Ciplukan & 0 & 3 & 0 & Berdaun lebar \\
5 & Poaceae & Eleusine indica (L.) Gaertn & Rumput belulang & 0 & 15 & 0 & Rerumputan \\
6 & Cyperaceae & Cyperus iria & Lingih alit & 0 & 2 & 14 & Teki-tekian \\
7 & Gramineae & Digitaria ciliaris Retz. Koel & Rumput jari & 0 & 20 & 0 & Rerumputan \\
8 & Fabaceae & Acacia mill & Akasia & 0 & 4 & 0 & Semak \\
9 & Asteraceae & Ageratum conyzoides & Wedusan & 0 & 3 & 0 & Berdaun lebar \\
10 & Cyperaceae & Cyperus rotundus & Teki & 10 & 14 & 64 & Teki-tekian \\
11 & Rubiaceae & Spermacoce alata & - & 2 & 4 & 0 & Berdaun lebar \\
12 & Cleomaceae & Cleome gynandra & - & 0 & 1 & 0 & Berdaun lebar \\
13 & Phyllanthaceae & Phyllanthus urinaria & Meniran & 0 & 0 & 11 & Berdaun lebar \\
\hline & Total & & & 237 & 179 & 242 & \\
\hline
\end{tabular}

Tabel 2. Struktur dan komposisi gulma pada lahan pertanaman kedelai di bawah naungan kelapa sawit

\begin{tabular}{|c|c|c|c|c|c|c|c|c|c|c|c|c|c|c|c|}
\hline \multirow{2}{*}{ Jenis } & \multicolumn{3}{|c|}{ KNSS (\%) } & \multicolumn{3}{|c|}{ FNSS (\%) } & \multicolumn{3}{|c|}{ DNSS (\%) } & \multicolumn{3}{|c|}{ NP } & \multicolumn{3}{|c|}{ SDR } \\
\hline & L1 & $\mathrm{L} 2$ & L3 & L1 & L2 & L3 & L1 & L2 & L3 & L1 & L2 & L3 & L1 & L2 & L3 \\
\hline nperata cylindrica & 85,23 & 51,40 & 57,44 & 35,71 & 23,08 & 28,57 & 85,23 & 51,40 & 57,44 & 206,18 & 125,87 & 143,45 & 85,23 & 351,40 & 57,44 \\
\hline icranopteris linearis & 9,71 & 4,47 & 4,96 & 35,71 & 10,26 & 11,43 & 9,71 & 4,47 & 4,96 & 55,12 & 19,20 & 21,35 & 9,70 & 4,47 & 4,96 \\
\hline $\begin{array}{l}\text { geratum } \\
\text { pustonianum }\end{array}$ & 0,00 & 7,26 & 0,83 & 0,00 & 12,82 & 2,86 & 0,00 & 7,26 & 0,83 & 0,00 & 27,35 & 4,51 & c & $\begin{array}{l}0 \\
0\end{array}$ & 0,83 \\
\hline hysalis minima. $L$ & 0,00 & 1,68 & 0,00 & 0,00 & 5,13 & 0,00 & 0,00 & 1,68 & 0,00 & 0,00 & 8,48 & 0,00 & c & $0 \quad 1,68$ & \\
\hline $\begin{array}{l}\text { leusine indica (L.) } \\
\text { aertn }\end{array}$ & 0,00 & 8,38 & 0,00 & 0,00 & 7,69 & 0,00 & 0,00 & 8,38 & 0,00 & 0,00 & 24,45 & 0,00 & c & 8,38 & \\
\hline Cyperus iria & 0,00 & 1,12 & 5,79 & 0,00 & 2,56 & 22,86 & 0,00 & 1,12 & 5,79 & 0,00 & 4,80 & 34,43 & c & 1,12 & 5,79 \\
\hline $\begin{array}{l}\text { Sigitaria ciliaris Retz. } \\
\text { Koel }\end{array}$ & 0,00 & 11,17 & 0,00 & 0,00 & 10,26 & 0,00 & 0,00 & 11,17 & 0,00 & 0,00 & 32,60 & 0,00 & & $0 \quad 11,17$ & \\
\hline cacia mill & 0,00 & 2,24 & 0,00 & 0,00 & 7,69 & 0,00 & 0,00 & 2,24 & 0,00 & 0,00 & 12,16 & 0,00 & $c$ & $0 \quad 2,23$ & \\
\hline geratum con & 0,00 & 1,68 & 0,00 & 0,00 & 5,13 & 0,00 & 0,00 & 1,68 & 0,00 & 0,00 & 8,48 & 0,00 & $c$ & 1,68 & 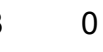 \\
\hline Cyperus rotundus & 4,22 & 7,82 & 26,45 & 25,00 & 7,69 & 17,14 & 4,22 & 7,82 & 26,45 & 33,44 & 23,34 & 70,04 & 4,22 & 27,82 & 26,44 \\
\hline Spermacoce alata & 0,84 & 2,24 & 0,00 & 3,57 & 5,13 & 0,00 & 0,84 & 2,24 & 0,00 & 5,26 & 9,60 & 0,00 & 0,85 & $5 \quad 2,23$ & 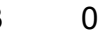 \\
\hline Cleome gynandra & 0,00 & 0,56 & 0,00 & 0,00 & 2,56 & 0,00 & 0,00 & 0,56 & 0,00 & 0,00 & 3,68 & 0,00 & c & $0 \quad 0,56$ & ; \\
\hline Phyllanthus urinaria & 0,00 & 0,00 & 4,56 & 0,00 & 0,00 & 17,14 & 0,00 & 0,00 & 4,55 & 0,00 & 0,00 & 26,23 & c & 0 & 4,54 \\
\hline
\end{tabular}

Indeks Shannon-Wiener (H')

Indeks keragaman gulma di setiap lokasi pemberian pupuk dasar (Tabel 3) juga diukur menggunakan standar keragaman Shannon-Wiener. Berdasarkan nilai indeks, nilai $H^{\prime}$ yang kurang dari 1 berarti keragaman jenis gulma pada tiap lokasi masih rendah (Tracy et al. 2004; Suryatini, 2018; Jastrzębska et al. 2013; Travlos et al.
2018). Kondisi ini salah satunya dipengaruhi oleh pemberian pupuk dasar yang dilakukan pada saat sebelum penanaman kedelai Susanto (2002) dan Hutapea et al. (2015) menyatakan bahwa terdapat kelemahan dan beberapa masalah dalam penggunaan pupuk organik antara lain jika dalam proses pembuatan pupuk organik pemurniannya tidak cukup baik, maka 
kemungkinan besar pupuk organik juga dapat membawa benih gulma atau gulma invasive.

Tabel 3. Indeks Shannon-Wiener ( $\left.\mathrm{H}^{\prime}\right)$ gulma pada lahan pertanaman kedelai di bawah naungan Kelapa Sawit

\begin{tabular}{lccc}
\hline \multirow{2}{*}{ Jenis } & \multicolumn{3}{c}{$\mathrm{H}^{\prime}$} \\
\cline { 2 - 4 } & $\mathrm{L} 1$ & $\mathrm{~L} 2$ & $\mathrm{~L} 3$ \\
\hline Imperata cylindrica & 0,26 & 0,36 & 0,35 \\
Dicranopteris linearis & 0,31 & 0,18 & 0,19 \\
Ageratum houstonianum & 0,00 & 0,22 & 0,06 \\
Physalis minima. L & 0,00 & 0,10 & 0,00 \\
Eleusine indica (L.) Gaertn & 0,00 & 0,20 & 0,00 \\
Cyperus iria & 0,00 & 0,07 & 0,25 \\
Digitaria ciliaris Retz. Koel & 0,00 & 0,24 & 0,00 \\
Acacia mill & 0,00 & 0,13 & 0,00 \\
Ageratum conyzoides & 0,00 & 0,10 & 0,00 \\
Cyperus rotundus & 0,25 & 0,20 & 0,34 \\
Spermacoce alata & 0,07 & 0,11 & 0,00 \\
Cleome gynandra & 0,00 & 0,05 & 0,00 \\
Phyllanthus urinaria & 0,00 & 0,00 & 0,21 \\
\hline
\end{tabular}

Keterangan: nilai $\mathrm{H}^{\prime}<1$ menunjukkan keragaman gulma di setiap lokasi pemberian pupuk dasar masih rendah

\section{KESIMPULAN}

1. Hasil penelitian teridentifikasi 10 famili gulma, yang terdiri dari 2 jenis gulma rumput, 7 jenis gulma berdaun lebar, dan 2 jenis gulma teki.

2. Gulma yang dominan pada lahan pertanaman kedelai adalah alang-alang.

\section{DAFTAR PUSTAKA}

Aldrich RJ, dan RJK. 1997. Principles in weed management. 2nd ed. Ameslowa: lowa State University Press.

Aldrich RJ. 1984. Weed-crop ecology, principles in weed management. Nort Scituate, Massachussets: Breton Publisher.

Barnes D, Chandapillai MM. 1972. Common malaysian weeds and their control. Kuala Lumpur: Berhad.

Caton BP, Mortimer M, Hill JE, Johnson DE. 2011. Gulma padi di Asia.

Franco A, Rufo, L and de la Fuente V. 2015. Fe Absorption and distribution of Imperata cylindrica (L.) P. Beauv. under controlled conditions. J. of Environmental \& Analytical Toxicology 05 (06). https://doi.org/10.4172/2161-0525.1000335.

Garrity DP, Soekardi M, Van Noordwijk M, De La Cruz R, Pathak PS, Gunasena HPM, Van N, Huijun G, Majid NM. 1996. The imperata grasslands of tropical asia: area, distribution, and typology. Agroforestry Systems $36 \quad(1-3):$ 3-29. https://doi.org/10.1007/BF00142865.

Gultom S, Zaman S, Purnamawati H. 2017. Periode kritis pertumbuhan kedelai hitam (Glycine max (L.) Merr) dalam berkompetisi dengan gulma. Bul Agrohorti. 5 (1)(1):45 - 54 .

Hendrival, Wirda Z, Azis A. 2014. Periode kritis tanaman kedelai terhadap persaingan gulma. Floratek. 9:6-13.
Hidayat S dan Rachmadiyanto AN. 2017. Utilization of alang-alang (Imperata cylindrica (L.) Raeusch.) as traditional medicine in Indonesian archipelago. Proc 1st SATREPS Conf. 1(0):82-89.

Hutapea C, Syofian M dan Sudirman A. 2015. Pengaruh berbagai jenis pupuk organik terhadap spesies gulma invasif 3(1):21-33.

Jastrzębska M, Jastrzębski, WP, Hołdyński C, and Kostrzewska MK. 2013. Weed species diversity in organic and integrated farming systems. Acta $\begin{array}{lll}\text { Agrobotanica } & 66 & \text { (3): }\end{array}$ https://doi.org/10.5586/aa.2013.045.

Kartikasari SD, Nurhatika S dan Muhibuddin A. 2013. Potensi alang-alang (Imperata cylindrica (L.) Beauv.) dalam produksi etanol menggunakan bakteri Zymomonas mobilis. J Sains dan Seni Pomits. 2(2):1-11.

Kastanja AY. 2015. Analisis komposisi gulma pada lahan tanaman sayuran. J Agroforestri. X (2): 107-114.

Kilkoda AK, Nurmala T, Widayat D. 2015. Pengaruh keberadaan gulma (Ageratum conyzoides dan Boreria alata) terhadap pertumbuhan dan hasil tiga ukuran varietas kedelai (Glycine max L. Merr) pada percobaan pot bertingkat. Kultivasi. 14(2):1-9. doi:10.24198/kltv.v14i2.12072.

Macdonald GE, Brecke BJ, Gaffney JF, Langeland KA, Ferrell JA, and Sellers BA. 2006. Cogongrass (Imperata cylindrica (L.) Beauv.) biology, ecology and management in Florida 1, 1-3. http://edis.ifas.ufl.edu.

Mercado B. 1979. Introduction to weed science. Los Banos, Laguna, the Philippines: Searca Pub.

Mohamad RB, Wibawa W, Mohayidin MG, Puteh AB, Juraimi AS, Awang $Y$ and Lassim MBM. 2010. Management of mixed weeds in young oil-palm plantation with selected broad-spectrum herbicides. Pertanika Journal of Tropical Agricultural Science 33 (2): 193-203.

Moody K, Munroe C, Lubigan R and Paller EC. 1984. Major weeds of the Philipines. Laguna, Philipines: Weed Science Society of the Philipines, University of the Philipines at Los Banos. College.

Najiyati S dan Danarti. 2003. Budidaya dan penanganan pascapanen. Edisi revisi. Yogyakarta: Kanisius.

Palijama W, Riry J dan Wattimena AY. 2012. 2012. Komunitas gulma pada pertanaman pala (Myristica fragrans $\mathrm{H}$.) belum menghasilkan dan menghasilkan di Desa Hutumuri Kota Ambon. Agrologia 1(2): 134142.

Perdana EO, Chairul and Syam Z. 2013. Analisis vegetasi gulma pada tanaman buah naga merah (Hylocereus polyrhizus L.) di Kecamatan Batang Anai, Kabupaten Padang Pariaman, Sumatera Barat. Jurnal Biologi Universitas Andalas 2 (4): 242-248.

Purnamasari CD, Yudo S, Sumarni T. 2017. Pengaruh teknik pengendalian gulma pada tanaman padi (Oryza sativa L.) J. Produksi Tanaman 5(5):870-879. 
Purnamasari ET, Yudono P, Rogomulyo R. 2016. Pertumbuhan gulma dan hasil kedelai hitam (Glycine max (L.) Merrill) 'Mallika' terhadap pengolahan tanah dan jarak tanam di lahan pasir pantai. Veg 2016 5(1) 23-31.

Saragih WS, Purba E, Tampubolon K. 2018. Identification and analysis of weed vegetation as ganoderma presence marker on oil palm plantation. $J$ Nat. 18:135-140. doi:10.24815/jn.v18i3.11595.

Sari, HFM dan Rahayu, SB. 2013. Jenis-jenis gulma yang ditemukan di perkebunan karet (Hevea brasiliensis Roxb) Desa Rimbo Datar Kabupaten 50 Kota Sumatera Barat. Biogenesis: Jurnal IImiah Biologi $\quad 1 \quad$ (1): 28-32. https://doi.org/10.24252/bio.v1i1.444.

Sellers BA, Farrell JA, MacDonals GE, Langeland KA, dan Flory SL. 2012. Cogongrass (Imperata cylindrica) biology, ecology and management in Florida grazing lands. The Institue of Food and Agrocultural Sciences $1-5$.

Silva AAP, Oliveira Neto AM, Guerra N, Helvig EO, Maciel CDG. 2015. Períodos de interferência entre plantas daninhas e a cultura da soja $r{ }^{\circledR}$ na região centro ocidental paranaense. Planta Daninha. 33(4):707-716. 83582015000400009.

Solahudin M, Seminar KB, Astika IW, Buono A. 2010. Pendeteksian kerapatan dan jenis gulma dengan metode bayes dan analisis dimensi fraktal untuk pengendalian gulma secara selektif. J Keteknikan Pertan. 24(2):129-136. doi:10.19028/jtep.24.2.129136.

Suryatini L. 2018. Analisis keragaman dan komposisi gulma pada tanaman padi sawah (studi kasus subak tegal Kelurahan Paket Agung Kecamatan Buleleng). Sains dan Teknol. 7(1):77-89.
Susanto R. 2002. Pertanian organik menuju pertanian alternatif dan berkelanjutan. Yogyakarta: Kanisius.

Syawal Y. 2009. Efek berbagai pupuk organik terhadap pertumbuhan gulma dan tanaman lidah buaya. J Agrivigor. 8 (3). Agu.

Tampubolon K, Purba E, Basyuni M, Hanafiah DS. 2019. Glyphosate resistance of Eleusine indica populations from North Sumatra, Indonesia. Biodiversitas. 20(7):1910-1916. doi:10.13057/biodiv/d200717.

Tampubolon K, Sihombing N, Purba Z, Samosir S, Karim S. 2018. Potensi metabolit sekunder gulma sebagai pestisida nabati di Indonesia. J Kultiv. 17(3):683-693.

Tantra AW dan Santosa E. 2016. Manajemen gulma di kebun kelapa sawit Bangun Bandar: analisis vegetasi dan seedbank gulma. Buletin Agrohorti 4 (2): 138-43. https://doi.org/10.29244/agrob.v4i2.15012.

Tjitrosoedirdjo S, Utomo IH, Wiroatmodjo. J. 1984. Pengelolaan gulma di perkebunan. Jakarta: Gramedia.

Tjitrosoepomo G, Soerjani M, Kostermans. 1987. Weeds of rice in Indonesia. Jakarta: Balai Pustaka.

Tracy BF, Renne IJ, Gerrish J, Sanderson MA. 2004. Effects of plant diversity on invasion of weed species in experimental pasture communities. Basic Appl Ecol. 5(6):543-550. doi:10.1016/j.baae.2004.08.007.

Travlos IS, Cheimona N, Roussis I, Bilalis DJ. 2018. Weed-species abundance and diversity indices in relation to tillage systems and fertilization. Front Environ Sci. 6(APR). doi:10.3389/fenvs.2018.00011.

Umiyati, U dan Kurniadie, D. 2016. Pergesaran populiasi gulma pada olah tanah dan pengendalian gulma yang berbeda pada tanaman. Kultivasi 15 (3): 150-53. https://doi.org/10.24198/kultivasi.v16i2.11761. 